\title{
Detection of Pre-C and Core Region Mutants of Hepatitis B Virus in Chronic Hepatitis B Virus Carriers
}

\author{
Takaji Wakita, Shinichi Kakumu, Motohiro Shibata,* Kentaro Yoshioka, Yuji Ito, Tadashi Shinagawa, \\ Tetsuya Ishikawa, Masahiro Takayanagi, and Tsuneo Morishima* \\ Third Department of Internal Medicine and *Department of Pediatrics, Nagoya University School of Medicine, Nagoya 466, Japan
}

\begin{abstract}
We analyzed the pre-C and core region of hepatitis $B$ virus (HBV) DNA by a polymerase chain reaction in 22 chronic carriers. In 9 hepatitis $B$ e antigen-positive asymptomatic carriers, a single DNA band was detected at the expected size, whereas additional shorter DNA bands were observed in 7 out of 11 patients with chronic hepatitis. The smaller-sized DNAs from one chronic hepatitis patient had various lengths of deletions spanning from 105 to $183 \mathrm{bp}$ in the middle of the core gene, and all deletions included common nucleotide sequences. All of the smaller-sized DNAs from the other patients proved to be variant core genes. They were deleted in similar regions by Southern analysis using oligonucleotide probes. A follow-up study revealed that four out of seven chronic hepatitis patients with a short core gene seroconverted to antibody to hepatitis B e antigen, but those with only a "wild type" did not. In another set of sequence studies, clones isolated from two chronic carriers displayed heterogeneity of the pre-C and core gene which was more often present in sera with normal alanine aminotransferase levels than with abnormal levels. These results suggest that mutant $\mathrm{HBV}$ alters the host immune response, and may modulate the clinical course of $\mathrm{HBV}$ infection. An alternative possibility is that chronic hepatitis selects for mutant forms. ( $J$. Clin. Invest. 1991. 88:1793-1801.) Key words: chronic hepatitis - deletion - point mutation - polymerase chain reaction • Southern blot hybridization
\end{abstract}

\section{Introduction}

During chronic hepatitis B virus (HBV) ${ }^{1}$ infection, some patients remain asymptomatic, whereas others exhibit active and

This study was presented in part at the 41 st Annual Meeting of the American Association for the Study of Liver Diseases on 5 November $1990 \mathrm{in}$ Chicago, IL, and was published in abstract form (1990. Hepatology (Baltimore). 12:886).

Address reprint requests to Dr. Wakita, Third Department of Internal Medicine, Nagoya University School of Medicine, 65 Tsurumacho, Showa-ku, Nagoya 466, Japan.

Received for publication 12 February 1991 and in revised form 18 July 1991.

1. Abbreviations used in this paper: ALT, alanine aminotransferase; anti-HBe, antibody to hepatitis B e antigen; ASC, asymptomatic carriers of hepatitis $B$ virus; $\mathrm{CH}$, chronic hepatitis; $\mathrm{CTL}$, cytotoxic T lymphocyte(s); DNA-P, DNA-polymerase; $\mathrm{HBcAg}, \mathrm{HBeAg}$, and $\mathrm{HBsAg}$, hepatitis $B$ core, $e$, and surface antigens, respectively; HBV, hepatitis $B$ virus; PCR, polymerase chain reaction.

J. Clin. Invest.

(C) The American Society for Clinical Investigation, Inc.

0021-9738/91/12/1793/09 \$2.00

Volume 88, December 1991, 1793-1801 progressive hepatitis. Alternatively, hepatitis may subside in patients who show seroconversion from hepatitis $B$ e antigen $(\mathrm{HBeAg})$ to antibody to $\mathrm{HBeAg}$ (anti-HBe). The host immune response to $\mathrm{HBV}$ antigens is believed to play an important role in the pathogenesis of the disease (1). However, it is not clear why the clinical courses are so diverse in each patient. Recent studies utilizing the polymerase chain reaction (PCR) have identified a new HBV strain with mutant DNAs in the pre-C/C region in chronic $\mathrm{HBV}$ carriers who seroconverted to anti-HBe $(2,3)$. It was found that a point mutation at the nucleotide position 1896 generates a novel stop codon at the carboxyl-terminal end of the pre-C region, thus making $\mathrm{HBeAg}$ production impossible. This defective pre-C variant may be associated with active hepatitis even in the presence of anti-HBe (4). These reports suggest the possibility of a mutation of viral genome influencing the clinical course of HBV infection. In the present study, using PCR, we amplified the HBV DNA core region (C-gene) coding hepatitis $\mathrm{B}$ core antigen $(\mathrm{HBcAg})$, which is thought to be a major target for cytotoxic $T$ lymphocytes (CTL) (5) in chronic carriers. Amplified DNAs were identified by Southern blot hybridization with two different Cgene-specific oligonucleotide probes and were subsequently subcloned for sequence analysis. We describe a long span of deletions in the middle of the C-gene, detected in a majority of chronic hepatitis $(\mathrm{CH})$ patients but not in asymptomatic carriers of $\mathrm{HBV}$ (ASC). Variations of the pre-C and C-gene in two chronic HBV carriers during their clinical course will also be shown.

\section{Methods}

Patients. 22 chronic HBV carriers were enrolled in this study. All patients were tested for hepatitis B surface antigen (HBsAg), $\mathrm{HBeAg}$, and anti-HBe using commercially available RIA kits (Abbott Laboratories, N. Chicago, IL). HBV-associated DNA polymerase (DNA-P) activity was assayed by determining $\left[{ }^{3} \mathrm{H}\right]$ thymidine incorporation (Tables I and II). Group A consisted of nine ASC positive for HBeAg. Patients were included in the study on the condition that clinical status and liver function tests were normal in repeated examinations over a 2- to 5-yr period. At the initiation of this study, all patients except case A1 were positive for DNA-P (Table I). Group B consisted of $11 \mathrm{HBeAg-positive}$ patients with $\mathrm{CH}$. Histological diagnosis was of chronic active hepatitis, and they had elevated serum ALT levels for at least $1 \mathrm{yr}$. Over a 3-yr follow-up interim, seven patients (B14-20) continually tested positive for $\mathrm{HBeAg}$, and the remaining four $(\mathrm{B} 10-13)$ seroconverted to anti$\mathrm{HBe}$ in $1.5 \mathrm{yr}$. Group C consisted of two $\mathrm{HBeAg}$-positive patients who had normal serum alanine aminotransferase (ALT) levels for $>1$ yr followed by undulation of liver function tests. Liver biopsy taken at the time of continuing elevated ALT levels revealed a histology consistent with chronic active hepatitis. Sera from group $C$ patients were obtained at two points, when ALT levels were normal and abnormal (Table II).

$P C R$. Serum $(100 \mu \mathrm{l})$ obtained from each patient was incubated at $70^{\circ} \mathrm{C}$ for $3 \mathrm{~h}$ in a mixture of proteinase $\mathrm{K}(100 \mu \mathrm{g} / \mathrm{ml}), 0.5 \%$ (wt/vol) SDS, $5 \mathrm{mM}$ EDTA, and $10 \mathrm{mM}$ Tris-HCl, pH 8.0. The solution was phenol-chloroform extracted, and DNA was precipitated with ethanol 


\begin{tabular}{|c|c|c|c|c|c|c|c|c|}
\hline \multirow[b]{2}{*}{ Group } & \multirow[b]{2}{*}{ Diagnosis } & \multirow[b]{2}{*}{ Patient } & \multirow[b]{2}{*}{ Age } & \multirow[b]{2}{*}{ Sex } & \multirow[b]{2}{*}{ ALT } & \multirow[b]{2}{*}{ DNA-P } & \multicolumn{2}{|c|}{ Size of C-gene } \\
\hline & & & & & & & $\begin{array}{l}\text { Normal } \\
(\sim 747 \mathrm{bp})\end{array}$ & $\begin{array}{c}\text { Short } \\
(\sim 500-700 \text { bp })\end{array}$ \\
\hline & & & $y r$ & & IU/liter & $c p m$ & & \\
\hline \multirow[t]{10}{*}{ A } & $\mathrm{HBeAg}^{+} \mathrm{ASC}$ & 1 & 28 & $\mathbf{F}$ & 28 & 0 & + & - \\
\hline & & 2 & 29 & $\mathrm{~F}$ & 46 & 2,346 & + & - \\
\hline & & 3 & 37 & $\mathrm{~F}$ & 35 & 10,286 & + & - \\
\hline & & 4 & 22 & $\mathrm{~F}$ & 19 & 595 & + & - \\
\hline & & 5 & 23 & $\mathrm{~F}$ & 24 & 2,627 & + & - \\
\hline & & 6 & 20 & $\mathrm{~F}$ & 36 & 220 & + & - \\
\hline & & 7 & 35 & $\mathbf{M}$ & 49 & 2,523 & + & - \\
\hline & & 8 & 37 & $\mathbf{M}$ & 37 & 8,361 & + & - \\
\hline & & 9 & 20 & $\mathrm{~F}$ & 42 & 1,302 & + & - \\
\hline & & Mean & 27.9 & $7 / 2$ & $35.0^{*}$ & 3,140 & $9 / 9(100 \%)$ & $0 / 9\left(0 \% \%^{\ddagger}\right)$ \\
\hline \multirow[t]{12}{*}{ B } & $\mathrm{HBeAg}^{+} \mathrm{CH}$ & 10 & 47 & $\mathbf{M}$ & 152 & 1,624 & + & + \\
\hline & & 11 & 38 & $\mathbf{M}$ & 204 & 1,294 & + & + \\
\hline & & 12 & 31 & $\mathbf{M}$ & 88 & 531 & + & + \\
\hline & & 13 & 29 & $\mathbf{F}$ & 87 & 11,452 & + & + \\
\hline & & 14 & 27 & $\mathbf{M}$ & 335 & 163 & + & + \\
\hline & & 15 & 25 & $\mathrm{~F}$ & 152 & 468 & + & + \\
\hline & & 16 & 36 & $\mathbf{F}$ & 117 & 3,219 & + & + \\
\hline & & 17 & 18 & $F$ & 141 & 1,143 & + & - \\
\hline & & 18 & 25 & $F$ & 446 & 122 & + & - \\
\hline & & 19 & 18 & $\mathbf{M}$ & 113 & 1,163 & + & - \\
\hline & & 20 & 25 & $\mathbf{M}$ & 169 & 692 & + & - \\
\hline & & Mean & 29.0 & $5 / 6$ & $182.2^{*}$ & 1,988 & $11 / 11(100 \%)$ & $7 / 11\left(63.4 \%^{\ddagger}\right)$ \\
\hline
\end{tabular}

Statistical analysis was performed between groups A and B.

${ }^{*} P<0.001 ;{ }^{\ddagger} P<0.01$.

Table II. Clinical Details of the Group C Patients and Isolated Clones

\begin{tabular}{|c|c|c|c|c|c|c|c|c|c|}
\hline Patient & Age & Sex & Date & ALT & DNA-P & $\mathrm{HBeAg}$ & Anti-HBc & Histology & Clones \\
\hline & & & & IU/liter & $c p m$ & $C I$ & \% inhibition & & \\
\hline \multirow[t]{5}{*}{$\mathrm{Cl}$} & 34 & $\mathbf{M}$ & 2 April 1988 & 31 & 3413 & 6.0 & 94.9 & & pHBC102 \\
\hline & & & & & & & & & 103 \\
\hline & & & & & & & & & $\begin{array}{l}106 \\
111\end{array}$ \\
\hline & & & 15 July 1989 & 143 & 343 & 6.3 & 100 & $\mathrm{CAH}$ & pHBC210 \\
\hline & & & & & & & & & 2221 \\
\hline \multirow[t]{6}{*}{$\mathrm{C} 2$} & 29 & $F$ & 9 March 1988 & 37 & 11974 & 6.6 & 95.8 & & pHBC307 \\
\hline & & & & & & & & & 309 \\
\hline & & & & & & & & & 3310 \\
\hline & & & & & & & & & 3314 \\
\hline & & & & & & & & & 3319 \\
\hline & & & 29 October 1989 & 156 & 36 & 7.8 & 95.7 & $\mathrm{CAH}$ & pHBC415 \\
\hline
\end{tabular}

Abbreviations: CAH, chronic active hepatitis; $\mathrm{CI}$, cutoff index. 
in the presence of carrier transfer RNA $(10 \mu \mathrm{g} / \mathrm{ml})$. Oligonucleotide primers, specific for $\mathrm{HBV}$ gene sequences, were synthesized in a DNA synthesizer, and included a sense primer HBC-1, 5'-TCTTTGTACTAGGAGGCTGTAGGC-3' (1765-1788, numbering according to Okamoto et al. [6]) and an antisense primer HBC-2, 5'-CAGGTACAGTAGAAGAATAAAGCCC-3' (2511-2487) capable of amplifying the HBV sequence from 1765 to 2511 to yield 747-bp DNA. This covered the entire pre-C and core region (639 bp, 1814-2452) and part of the $\mathrm{X}$ and polymerase gene. The PCR reaction was conducted in a $100-\mu \mathrm{l}$ mixture containing $10 \mu \mathrm{l}$ of the serum DNA sample, $2.5 \mathrm{U}$ of Taq polymerase (Perkin-Elmer Cetus, Norwalk, CT), $50 \mu \mathrm{M}$ of each $\mathrm{dNTP}$, and $0.4 \mu \mathrm{M}$ of each primer (HBC-1 and HBC-2). The reaction was cycled 35 times with 1 min of denaturation at $94^{\circ} \mathrm{C}, 30$ s of annealing at $64^{\circ} \mathrm{C}$, and $3 \mathrm{~min}$ of extension at $72^{\circ} \mathrm{C}$ in a programmable DNA thermal cycler (Perkin-Elmer Cetus). For each sample, a 10- $\mu$ l aliquot of the amplified DNA was fractionated by $1 \%$ Seakem $/ 2 \%$ NuSieve agarose (FMC BioProducts, Rockland, ME) electrophoresis. The DNA was visualized by ultraviolet fluorescence after staining with ethidium bromide, and was then transferred to a nylon membrane (Nytran-N, Schleicher \& Schuell, Kassel, FRG) for Southern blot hybridization analysis.

Southern blot analysis. Two oligonucleotide probes derived from an internal sequence of the C-gene were synthesized: HBC-7, 5'CTGTGGAGTTACTCTCTTTTTTGC-3' (1934-1958), and HBC-9, 5'-ATGTCAATGTTAATATGGGCCTAAAAATCAGA-3' (21632194). The membranes were prehybridized at $53^{\circ} \mathrm{C}$ for $2 \mathrm{~h}$ in $3 \times$ Denhardt's solution $(1 \times$ Denhardt's solution $=0.02 \%$ polyvinylpyrrolidone, $0.02 \%$ Ficoll, and $0.02 \%$ bovine serum albumin); $0.1 \%$ SDS; $2 \times$ SSC $(1 \times \mathrm{SSC}=0.15 \mathrm{M} \mathrm{NaCl}$ and $0.015 \mathrm{M}$ sodium citrate); and 200 $\mu \mathrm{g} / \mathrm{ml}$ denatured salmon sperm DNA. Blots were hybridized with ${ }^{32} \mathrm{P}$ end-labeled $\mathrm{HBC}-7$ probe at $53^{\circ} \mathrm{C}$ for $24 \mathrm{~h}$. After hybridization, membranes were washed twice in $0.2 \times \mathrm{SSC}$ and $0.1 \%$ SDS at $43^{\circ} \mathrm{C}$, and then autoradiographed by exposure to x-ray film (XAR, Eastman Kodak Co., Rochester, NY). After autoradiography, the hybridized HBC-7
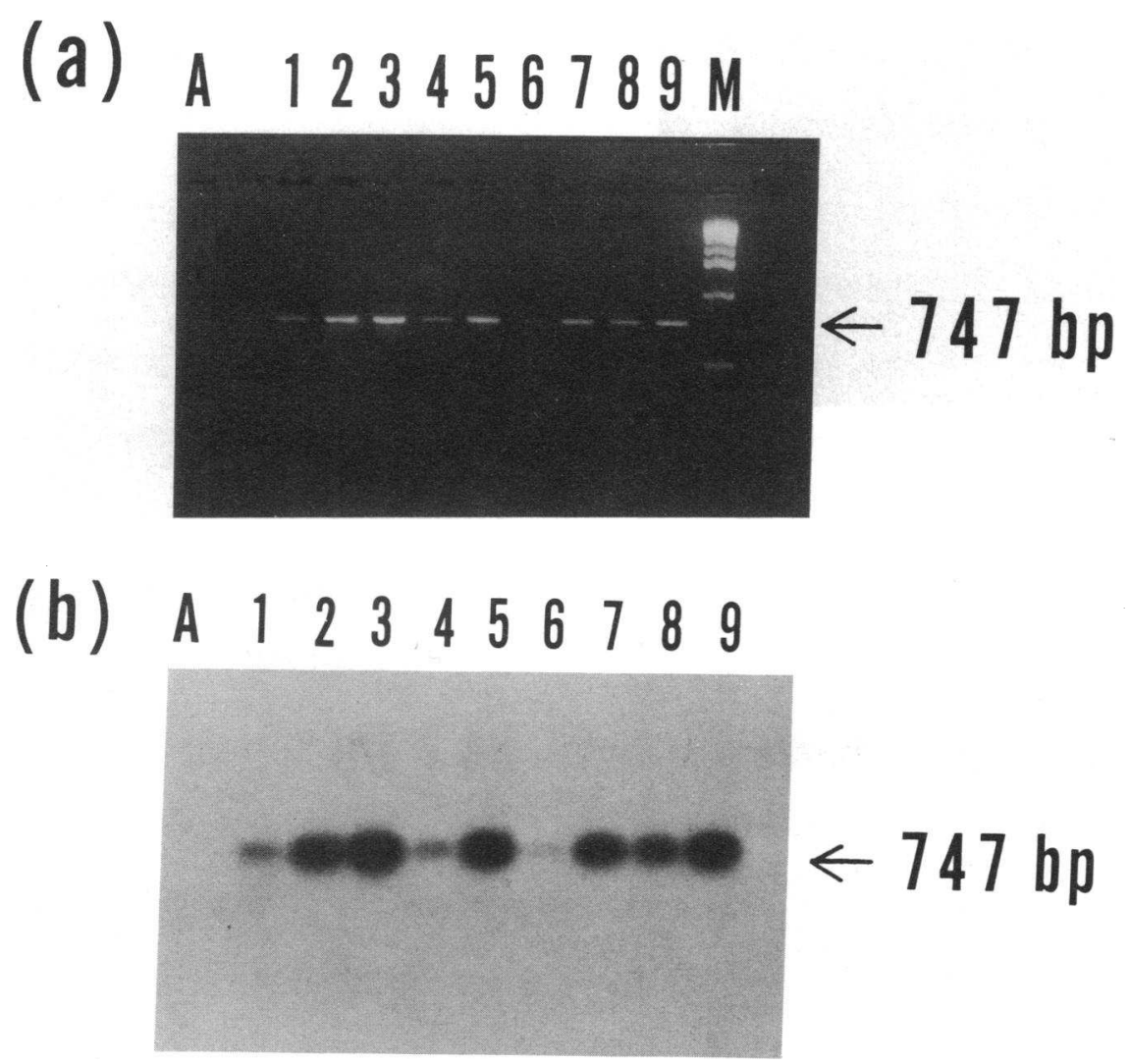

\section{(c) A 123456789}

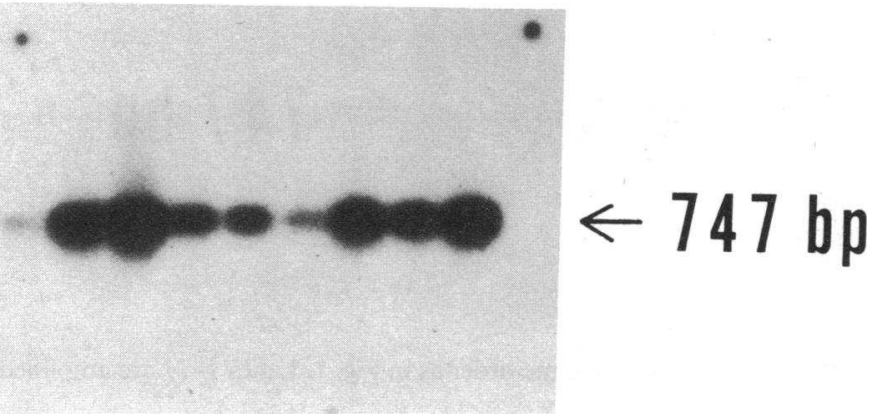

Figure 1. Detection of core region of $\mathrm{HBV}$ DNA by PCR and hybridization in patients with nine ASC. Shown are bands of the ethidium bromide-stained gel electrophoresis $(a)$ and autoradiography of the hybridized transfer with HBC-7 $(b)$ and HBC-9 (c). Lanes 1-9 are PCR products from patients A1-9, respectively. Lane $M$ is the size marker, $1 \mathrm{~kb}$ DNA ladder. 
probe was removed by boiling twice in $0.1 \times \mathrm{SSC}$ and $0.1 \%$ SDS. Membranes were rehybridized with ${ }^{32} \mathrm{P}$-end-labeled HBC-9 probe by the same procedure as described above.

Cloning and sequencing. From case B1 and 2 patients of group C, amplified DNAs were cloned into the Smal site of plasmid pGEM7Zf + ) (Promega Biotec, Madison, WI). These clones were sequenced by the dideoxy chain termination method.

Statistical analysis. Data was analysed by the Student's $t$ or $\chi^{2}$ test.

\section{Results}

The sensitivity of PCR was determined with a serial dilution of cloned HBV DNA; the lower limit of detection of HBV DNA was $10^{-2} \mathrm{pg}$ using the ethidium bromide staining method (data not shown).

In all sera derived from eight ASC of group A, a single DNA band was visible at the expected size $(\sim 747 \mathrm{bp})$ on the ethidium-bromide-stained agarose gel (A1-8, Fig. 1 a) after PCR. 11 $\mathrm{CH}$ patients in group B also had a DNA band at $\sim 747 \mathrm{bp}$. However, in seven patients (63.6\%) with $\mathrm{HBeAg}$-positive $\mathrm{CH}$ (B10-16, Fig. $2 a$ ), additional short DNA bands ( 500-700 bp) were observed. During follow-up studies, four out of seven group B patients with additional short DNA bands seroconverted to anti-HBe positive, whereas the three with only a 747bp DNA "wild-type" band did not.

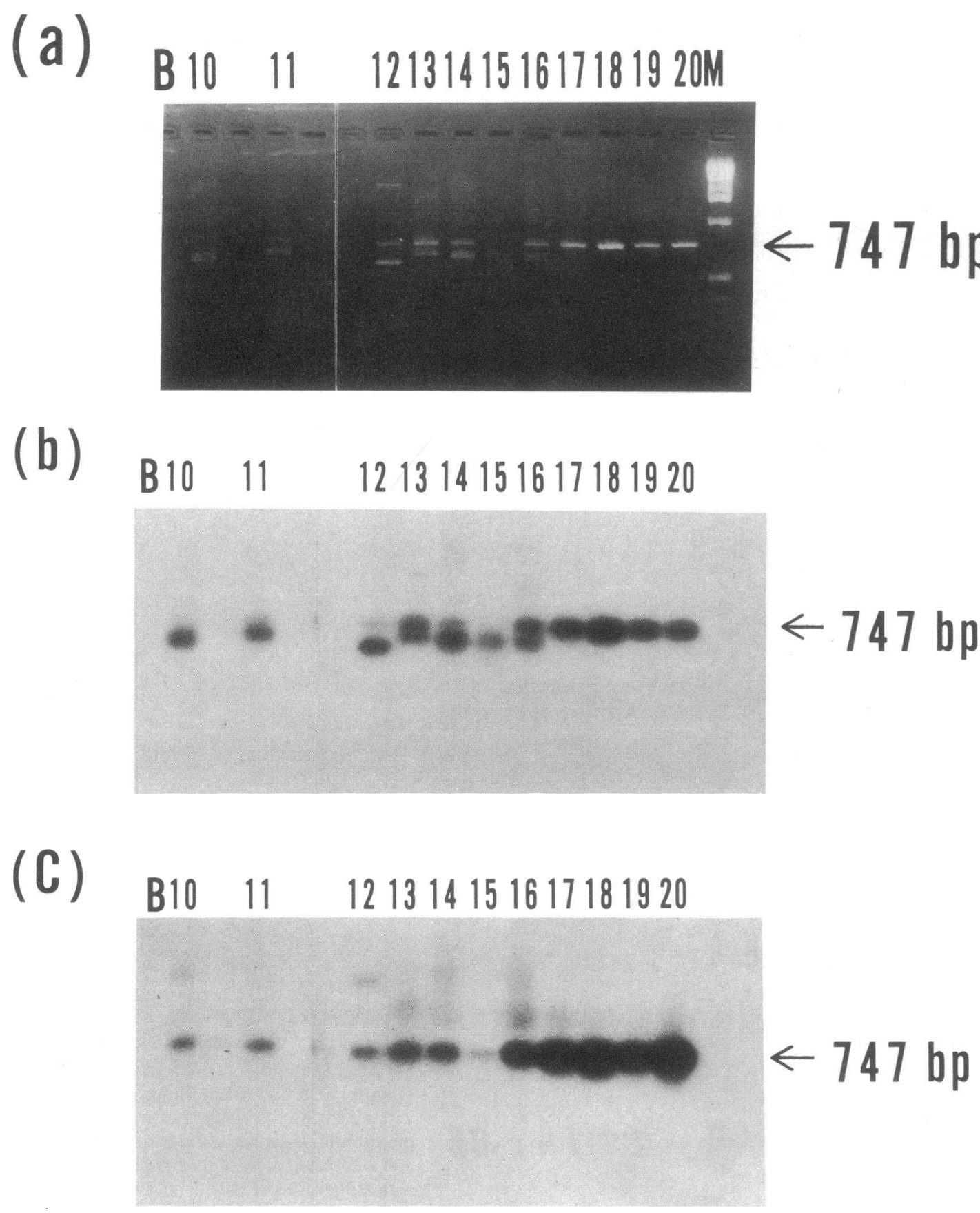

Figure 2. Detection of core genes in $11 \mathrm{CH}$ patients. Bands are shown in the same order as in Fig. 1. Lanes 1-11 are amplified core genes of cases B10-20, respectively. 
By cloning analysis of amplified DNA obtained from patient $\mathrm{B} 10$, six independent clones were isolated and characterized (Fig. 3). Among them, one pHBC601 clone had complete pre-C and core region gene of HBV. The other five had the same sequences at both the $5^{\prime}$ and $3^{\prime}$ ends as pHBC601, but more notably, sizes were shorter than pHBC601. Deletions of various sizes (105-183 bp) in the middle of the C-gene were obtained. Clone pHBC607 had the shortest deletion (105 bp, 2150-2254), and we found it commonly deleted in the four other clones as well. Since the sizes of the deletions were in multiples of three, none caused frameshift alterations, and these "in-frame" deletion variants could be translated through to the end of the C-gene.

Southern blot hybridization analysis using oligonucleotide probes HBC-9 for the common deletion probe, and HBC-7 for the conserved region probe, demonstrated that all $\sim 747$ bp DNA bands hybridized with both HBC-7 and HBC-9. In contrast, the short DNA bands hybridized with $\mathrm{HBC}-7$, but not with HBC-9 (Figs. 1 and 2). These results suggest that all short DNA bands were mutant core region genes similar to those observed in patient B10.

To evaluate if variations of nucleotide sequence in $\mathrm{HBV}$ DNA may induce alteration of the clinical status, we selected two chronic HBV carriers who had normal liver function and subsequent elevation of serum ALT levels.

In patient $\mathrm{C} 1$, four independent clones (pHBC102, 103, 106 , and 1111) were obtained from serum with normal ALT levels, and two clones (pHBC210 and 2221) with abnormal ALT (Table II). The entire pre-C and core gene sequences of pHBC102 are shown in Fig. 4, and the point mutations of the other clones are indicated in Fig. 5. Compared with pHBC102, pHBC103 had two point mutations of nucleotide sequence (C to $T$, at 1935 and 2290). The former mutation at 1935 changed the amino acid, serine to phenylalanine, and the latter was a silent mutation which did not change the amino acid sequence. Only one point mutation occurred in $\mathrm{pHBC106}$ (C to A, at 2288), which changed proline to threonine. Thymidine insertion occurred in pHBC1111 between 1956 and 1957 and caused a frameshift. One of the clones obtained from the serum with abnormal ALT, pHBC2221 had sequences identical to pHBC102. Between 1825 and 1826, pHBC210 had a 2-bp insertion (TT) which induced a frameshift and stop codon in the pre- $C$ region. Although the pre- $C$ region was defective in pHBC210, its C-gene was completely conserved.

In patient $\mathrm{C} 2$, five clones (pHBC307, 309, 3310, 3314, and 3319) from serum with normal ALT levels and two clones (pHBC415 and 4402) with abnormal ALT levels were isolated (Table II, Figs. 4 and 6). A long span of nucleotide deletion ( 149 and $269 \mathrm{bp}$ ) was found in the midsequence for pHBC307 and 3314. The deletion of pHBC307 caused a frameshift. Between 1921 and 1922, pHBC3314 had a 1-bp insertion (A). This insertion also caused a frameshift resulting in the termination of translation before deletion. Compared with pHBC309, pHBC3310 had only one point mutation $C$ to $T$ at 2242 . This mutation was silent and commonly observed with pHBC 3319 , 415, and 4402 as well. Compared with pHBC309, pHBC3319 had six point mutations. Although the mutation at 2242 was silent, the other five mutations were accompanied by changes in amino acid sequences (Fig. 6). Although showing 10 point mutations, pHBC415 had complete pre-C and C-gene. In the pre-C region, pHBC4402 had one thymidine deletion between 1821 and 1825 which caused a frameshift and termination of translation. Nine mutations occurred in pHBC4402 out of which amino acids changed sequence in six.

Complete pre-C and core genes were found in pHBC102 and 2221. Similar nucleotide sequences were also found in patient $\mathrm{C} 1$. However, identical clones were not found in the two different sera taken from patient $\mathrm{C} 2$ during the clinical course. The defect of the pre-C region, which cannot produce $\mathrm{HBeAg}$, was observed in the sera from both patients with elevations of ALT.

\section{Discussion}

Recent studies in HBV infection have utilized the PCR technique $(7,8)$. This highly sensitive method enables us the cloning of small amount of viral DNA. However, the PCR technique has a risk of copy errors and cross-contamination among

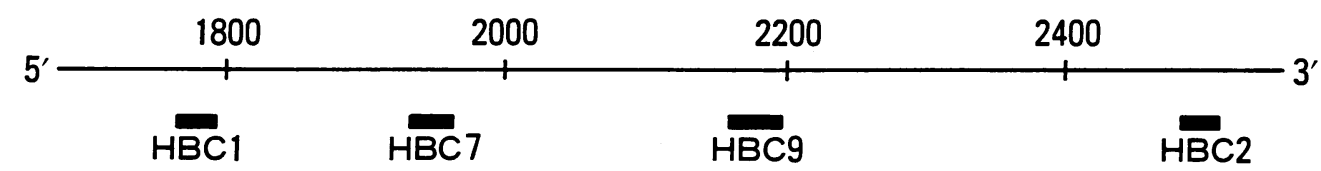

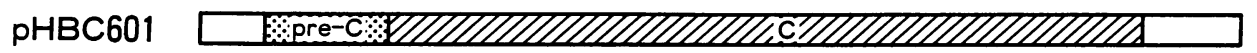

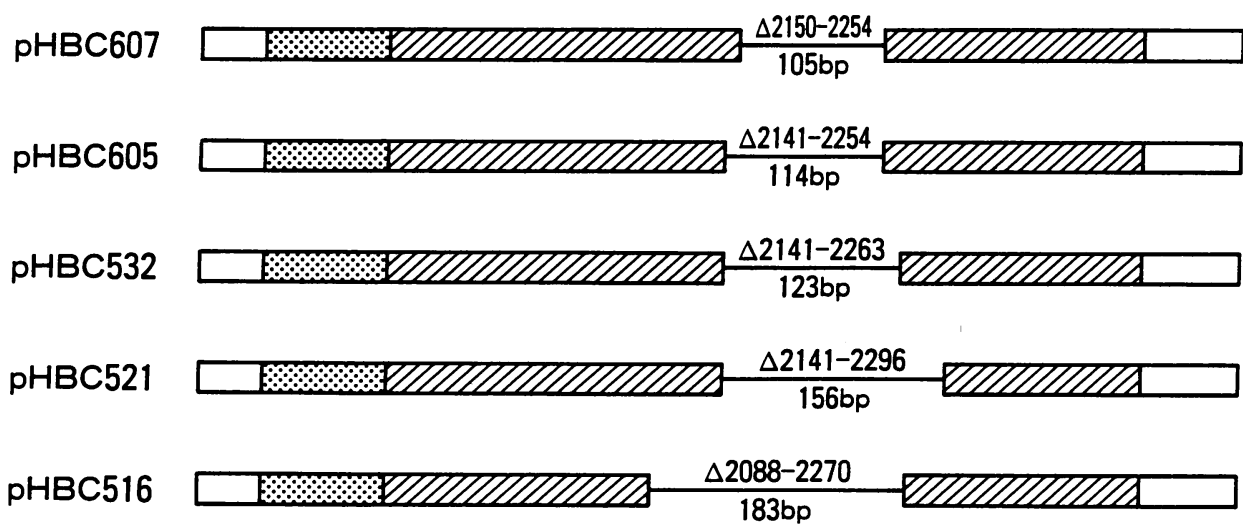

Figure 3. Six core region HBV DNA clones obtained from case B10. Nucleotide numbering is represented above. Positions of PCR primers (HBC-1 and HBC-2) and probes for Southern blot analysis (HBC-7 and HBC-9) are indicated by short closed bars. The dotted portion of the bars is for the pre-C region, and the shaded portion is for the core region of $\mathrm{HBV}$ DNA. 
$\Rightarrow$ pre-C

PHBC102 ATGCAACTTTTTCACCTCTGCCTAATCATCTCATGTTCATGTCCTACTGTTCAAGCCTCC

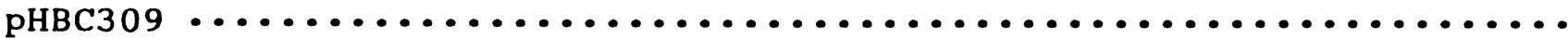
$\Rightarrow \mathrm{C}$

AAGCTGTGCCTTGGGTGGCTTTGGGGCATGGACATTGACCCGTATAAAGAATTTGGAGCT

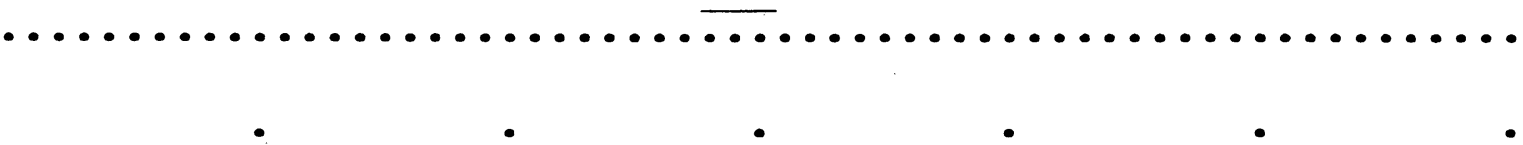
TCTGTGGAGTTACTCTCTTTTTTGCCTTCTGACTTCTTTCCTTCTATTCGAGATCTCCTC $\ldots \ldots \ldots \ldots \ldots \ldots \ldots \ldots \ldots \ldots \ldots \ldots \ldots \ldots \ldots \ldots \ldots \ldots \ldots \ldots \ldots \ldots \ldots \ldots \ldots \ldots \ldots \ldots \ldots \ldots$ GACACCGCCTCTGCTCTGTATCGGGAGGCCTTAGAGTCTCCGGAACATTGTTCACCTCAC $\ldots \ldots \ldots \ldots \ldots \ldots \ldots \ldots \ldots \ldots \ldots \ldots \ldots \ldots \ldots \ldots \ldots \ldots \ldots \ldots \ldots \ldots \ldots \ldots \ldots \ldots \ldots \ldots \ldots \ldots \ldots \ldots \ldots \ldots$ CATACAGCACTCAGGCAAGCTATTCTGTGTTGGGGTGAGTTGATGAATCTGGCCACCTGG $\ldots \ldots \ldots \ldots \ldots \ldots \ldots \ldots \ldots \ldots \ldots \ldots \ldots \ldots \ldots \ldots \ldots \ldots \ldots \ldots \ldots \ldots \ldots \ldots \ldots \ldots \ldots \ldots \ldots \ldots \ldots \ldots$ GTGGGAAGTAATTTGGAAGATCCAGCATCCAGGGAATTAGTAGTCAGCTATCTCAATGTT

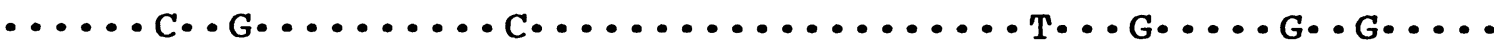

\section{AATATGGGCCTAAAAATCAGACAACTATTGTGGTTTCACATTTCCTGTCTTACTTTTGGA}

AGAGAAACTGTTCTCGAATATTTGGTGTCTTTTGGAGTGTGGATTCGCACTCCTCCCGCT $\ldots \ldots \ldots \ldots . \ldots \ldots \ldots \ldots \ldots \ldots \ldots \ldots \ldots \ldots \ldots \ldots \ldots \ldots \ldots \ldots \ldots \ldots \ldots \ldots \ldots \ldots \ldots \ldots \ldots \ldots \ldots \ldots \ldots \ldots$ TACAGACCACCAAATGCCCCTATCTTATCAACACTTCCGGAAACTACTGTTGTTAGACGA . Т........................................ CGAGGCAGGTCCCCTAGAAGAAGAACTCCCTCGCCTCGCAGACGAAGATCTCAATCGCCG

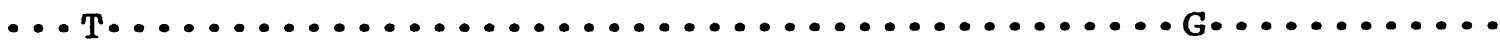
CGTCGCAGAAGATCTCAATCTCGgGAATCTCAATGTTAG

\section{CGTCGCAGAAgATCTCAATCTCGgGaATCTCAaTGT}

Figure 4. The entire pre-C and core gene sequences of pHBC102 and pHBC309.

samples. Therefore, special care was taken to avoid the known pitfalls of PCR (9). To ensure accuracy, different sera obtained separately from the same patients were tested, and results were repeatedly confirmed. In this study, we amplified entire pre-C and core gene coding $\mathrm{HBcAg}$ and $\mathrm{HBeAg}$. We obtained only the expected size of the C-gene from ASC, whereas the short $\mathrm{C}$-genes were detected as well from $>60 \%$ of the patients with $\mathrm{HBeAg}$-positive $\mathrm{CH}$. By clonal analysis, short DNAs were 


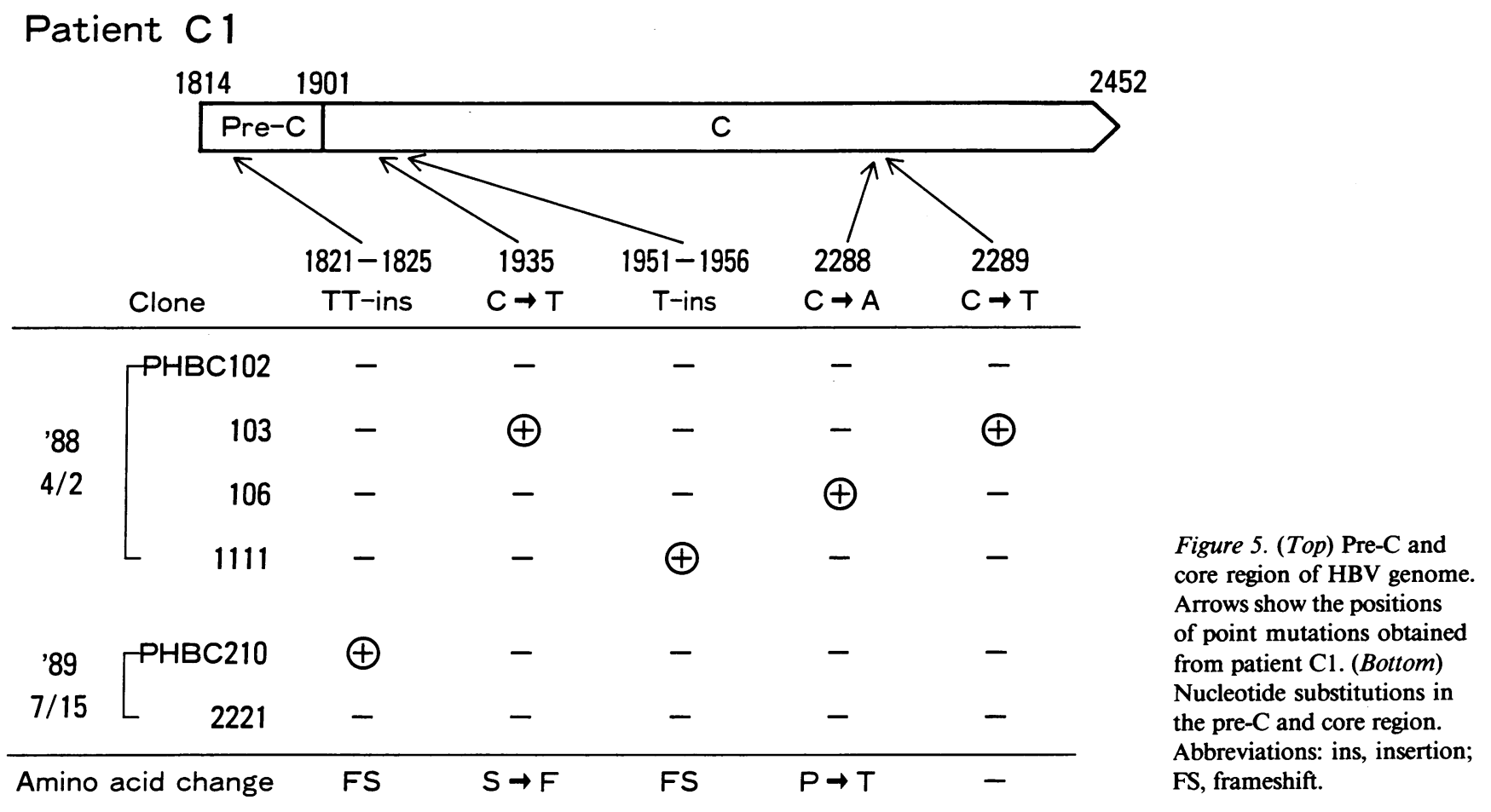

shown to be mutant C-genes with a long span of deletions including nucleotides 2150-2254. These deletions may be a common molecular feature of $\mathrm{CH}$ patients with short DNA bands. This was demonstrated by the Southern blot analysis using an oligonucleotide probe common for the deletion site.

The core gene depends on some cis-acting control signal sequences and overlaps with other open reading frames (10). The core deletion, however, did not overlap with the polyadenilation signal (1917-1960), direct repeat 1 (1824-1834), the polymerase gene (2307-1623), or the X-gene (1374-1838). Recently, the RNA packaging signal has been reported as another cis-acting element which extends over the pre-C and core gene (1819-1988) (11). Although pHBC3314 lacks 269 bp of Cgene, and 10-bp overlaps with $3^{\prime}$ terminal of the packaging signal, no other core deletions overlapped with it.

$\mathrm{HBcAg}$ and $\mathrm{HBeAg}$ are considered major target antigens for $T$ cell-mediated hepatocellular damage in patients with chronic HBV infection $(5,12)$. However, factors that determine the immunological response to viral products are not fully understood (13). Also, the short C-genes detected in this study must be tested to see whether they affect the pathogenesis of hepatocellular injury in chronic hepatitis or are actually the result of immunological pressure.

If these short C-gene mutants are translated in infected cells, a shortened $\mathrm{HBcAg}$ or $\mathrm{HBeAg}$ will be produced. In fact, all deletions obtained in case $\mathrm{B} 10$ were in multiples of three, as "in-frame" deletions. The expected $\mathrm{HBcAg}$ or $\mathrm{HBeAg}$ should have had deletions of amino acids located within 63-132 amino acids from the amino terminus of $\mathrm{HBcAg}$. This region contains hydrophilic sites, which may act as antibody binding sites $(14,15)$, and may represent a helper $T$ cell epitope (16). The loss of these epitopes could affect the binding of antigen and antibody. The CTL epitopes against $\mathrm{HBcAg}$ and $\mathrm{HBeAg}$ have not yet been precisely determined, but they could be located close to antibody binding sites since anti-HBc and anti$\mathrm{HBe}$ inhibit the CTL response in vitro $(5,12)$. Thus, an alteration or deletion of the binding sites of an antibody and de- graded fragments of viral proteins such as a deletion mutant-derived antigen not detectable serologically may change the activities of CTL targeting both antigens present on HBV infected hepatocytes in vivo (17-19).

The heterogeneity of HBV DNA in chronic carriers has been reported by others (20-22). We also found a variety of the $\mathrm{C}$-gene variants in the sera of two chronic carriers. Because Taq-polymerase does not have proofreading activity, it is possible that base-pair changes in obtained clones may include artifacts introduced at an early stage of the amplification process $(23,24)$. To minimize errors caused by Taq-polymerase during PCR, $\mathrm{HBeAg}-$ and DNA-P-positive sera were used as starting templates since they contained a fairly large number of $\mathrm{HBV}$ genomes. Variations of the nucleotide sequence were then compared within isolated clones, and consensus sequences for each clone were established. The number of the isolated clones and DNA-P levels from sera with abnormal ALT levels decreased when compared to those of sera with elevated ALT values in both patients (Table II). During this period, some viral strains were probably cleared by the host immune responses, although others escaped from the attack and continued to produce $\mathrm{HBeAg}$. However, a cause and effect relationship has not been clarified between viral mutagenesis and liver disease activity.

Deletion or insertion between the positions 1821 and 1825 in the pre-C region was observed in both patients of group $\mathrm{C}$, and this mutation renders impossible the production of $\mathrm{HBeAg}$. The mutation in this region was noted in anti-HBepositive patients by other investigators $(2,25)$. The point mutation at $1896, \mathrm{G}$ to $\mathrm{A}$, was not found in this study, although other types of defective pre-C variations did occur in $\mathrm{HBeAg}$ positive patients. Carman et al. (4) also suggested defective pre$\mathrm{C}$ variants were present in some of the $\mathrm{HBeAg}$-positive patients.

The findings of HBV core region gene deletion and mutations must be placed in the general context of gene replication and substitution. The HBV genome is a partial double- 


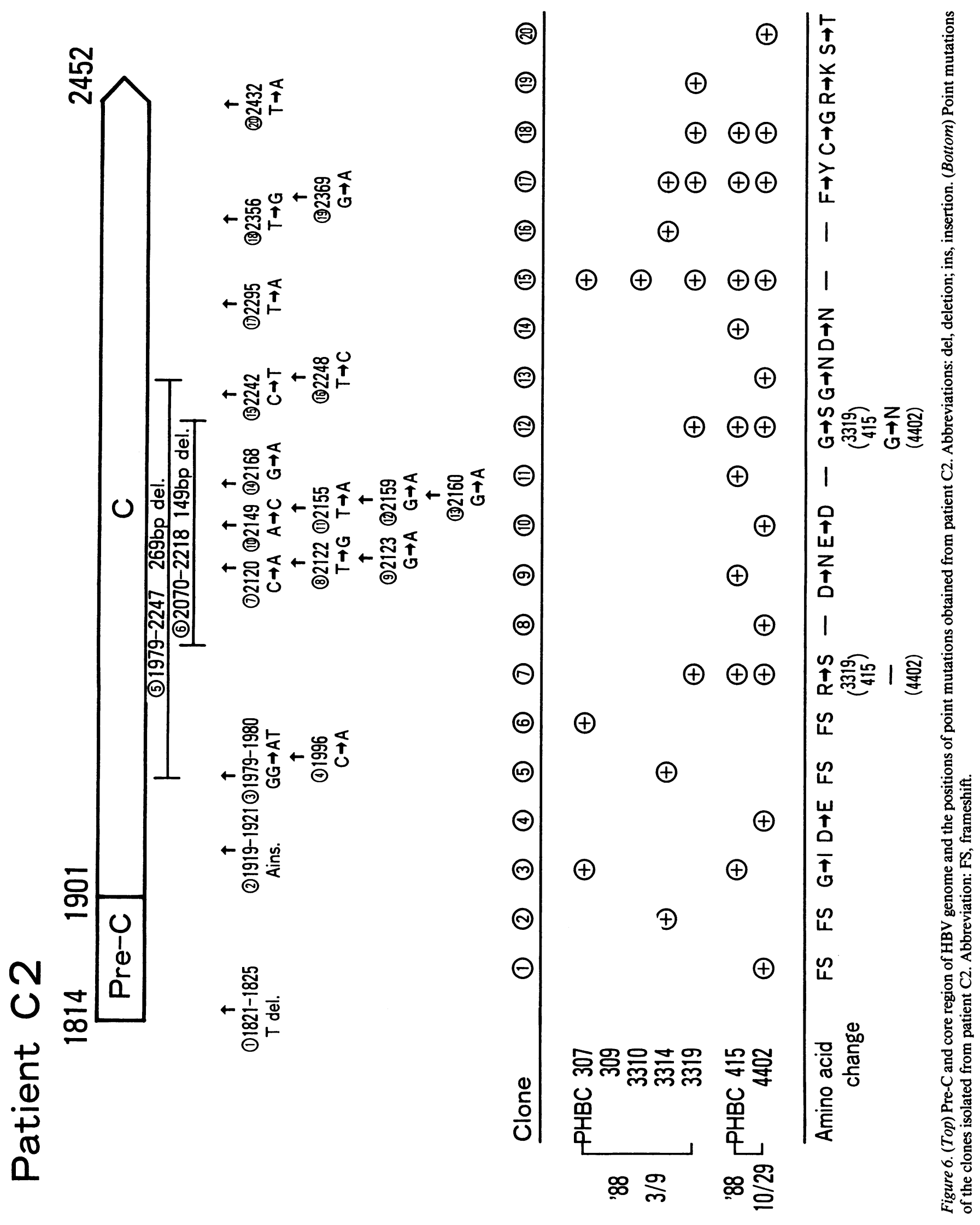

1800 Wakita et al. 
stranded DNA (26). The central feature of the replication mechanism is the use of an RNA template intermediate with reverse transcription similar to retroviruses (27). Thus, HBV is likely to mutate at a rate of nucleotide substitutions per site per year estimated at $1.4 \times 10^{-5}$ to $3.2 \times 10^{-5}(20)$. This ratio is higher than most DNA viruses, and is in the same order of magnitude as some retroviruses. Mutations are likely to occur during transcription and reverse transcription between RNA and DNA when HBV replicates frequently. Mutations may also affect biological properties of $\mathrm{HBV}(28,29)$. In recent studies, some spliced RNAs were identified from $\mathrm{HBV}$-infected cells and their origin was thought to be a 3.3-kb pregenomic RNA (30, $31)$. Thus, deleted core region DNA may be the product of reverse transcription of these or unknown types of spliced RNAs.

In conclusion, deleted mutants of HBV DNA in the core region were found to exist in more than half of the patients with $\mathrm{CH}$. Also, heterogeneity was found in the nucleotide sequences of the pre- $\mathrm{C}$ and core gene including defective mutants in pre-C with chronic HBV carriers. Products of these variant genes may change the immunological properties of $\mathrm{HBcAg}$ or $\mathrm{HBeAg}$, and subsequently, the clinical courses of chronic HBV carriers. An alternative possibility is that chronic hepatitis or the accompanying immune response opts for mutant forms. Clarification is necessary to determine if these core mutations are the cause or result of immune provocation. Further investigation must be undertaken to see whether the mutant core antigens alter CTL responses in vitro, if mutant core antigens are found in virions, and if mutant genomes are replication competent.

\section{Acknowledgments}

We thank Dr. Masashi Mizokami and Dr. Etsuro Orido for helpful discussions throughout the project.

\section{References}

1. Dudley, F. J., R. A. Fox, and S. Sherlock. 1972. Cellular immunity and hepatitis associated Australia antigen liver disease. Lancet. $i: 723-726$.

2. Okamoto, H., S. Yotsumoto, Y. Akahane, T. Yamanaka, Y. Miyazaki, Y. Sugai, F. Tsuda, T. Tanaka, Y. Miyakawa, and M. Mayumi. 1990. Hepatitis B viruses with precore region defects prevail in persistently infected hosts along with seroconversion to the antibody against e antigen. J. Virol. 64:1298-1303.

3. Brunetto, M. R., M. Stemler, F. Bonino, F. Schodel, F. Oliveri, M. Rizzetto, G. Verme, and H. Will. 1990. A new hepatitis B virus strain in patients with severe anti-HBe positive chronic hepatitis B. J. Hepatol. 10:258-261.

4. Carman, W. F., M. R. Jacyna, S. Hadziyannis, P. Karayiannis, M. J. McGarvey, A. Markis, and H. C. Thomas. 1989. Mutation preventing formation of hepatitis B e antigen by in patients with chronic hepatitis B infection. Lancet. ii:588-590.

5. Mondelli, M., G. M. Vergani, A. Alberti, D. Vergani, B. Portmann, A. L. W. F. Eddleston, and R. Williams. 1982. Specificity of T-lymphocyte cytotoxicity to autologous hepatocytes in chronic hepatitis $B$ virus infection: evidence that T-cells are against $\mathrm{HBV}$ core antigen expressed on hepatocytes. J. Immunol. 129:2773-2778.

6. Okamoto, H., M. Imai, M. Shimozaki, Y. Hoshi, H. lizuka, T. Gotanda, F. Tsuda, Y. Miyakawa, and M. Mayumi. 1986. Nucleotide sequence of a cloned hepatitis B genome, subtype ayr: comparison with genomes of the other three subtypes. J. Gen. Virol. 67:2305-2314.

7. Kaneko, S., R. H. Miller, S. M. Feinstone, M. Unoura, K. Kobayashi, N. Hattori, and R. H. Purcell. 1989. Detection of serum hepatitis B virus DNA in patients with chronic hepatitis using the polymerase chain reaction assay. Proc Natl. Acad. Sci. USA. 86:312-316.

8. Liang, T. J., K. J. Isselbacher, and J. R. Wands. 1989. Rapid identification of low level hepatitis B or variant viral genome in serum. J. Clin. Invest. 84:13671371.

9. Kwok, S., and R. Higuchi. 1989. Avoiding false positive with PCR. Nature (Lond.). 339:237-238.

10. Miller, R. H., S. Kaneko, C. T. Chung, R. Girones, and R. H. Purcell. 1989. Compact organization of the hepatitis B virus genome. Hepatology (Baltimore). 9:322-327.

11. Junker-Niepmann, M., R. Bartenschlager, and H. Schaller. 1990. A short cis-acting sequence is required for hepatitis $B$ virus pregenome encapsidation and sufficient for packaging of foreign RNA. EMBO (Eur. Mol. Biol. Organ.) J. 9:3389-3396.

12. Pignatelli, M., J. Waters, and H. C. Thomas. 1985. Evidence that cytotoxic $\mathrm{T}$ cells sensitized to $\mathrm{HBeAg}$ are responsible for hepatocyte lysis in chronic hepatitis B virus infection. Hepatology (Baltimore). 5:988A. (Abstr.)

13. Ferrari, C., A. Penna, A. DegliAntoni, and F. Fiaccadori. 1988. Cellular immune response to hepatitis B virus antigens. J. Hepatol. 7:21-33.

14. Salfeld, J., E. Pfaff, M. Noah, and H. Schaller. 1989. Antigen determinants and functional domains in core antigen and $e$ antigen from hepatitis B virus. $J$. Virol. 63:798-808.

15. Colucci, G., Y. Beazer, C. Cantaluppi, and C. Tackney. 1988. Identification of a major hepatitis $\mathrm{B}$ core antigen $(\mathrm{HBcAg})$ determinant by using synthetic peptides and monoclonal antibodies. J. Immunol. 141:4376-4380.

16. Milich, D. R., A. McLachlan, A. Moriarty, and G. B. Thornton. 1987. Immune response to hepatitis $B$ virus core antigen $(\mathrm{HBcAg})$ : localization of $\mathrm{T}$ cell recognition sites within $\mathrm{HBcAg} / \mathrm{HBeAg}$. J. Immunol. 139:1223-1231.

17. Townsend, A., J. Bastin, K. Gould, G. Brownlee, M. Andrew, B. Coupar, D. Boyle, S. Chan, and G. Smith. 1988. Defective presentation to class I-restricted cytotoxic T lymphocytes in vaccinia-infected cells is overcome by enhanced degradation of antigen. J. Exp. Med. 168:1211-1224.

18. Townsend, A. R. M., J. Bastin, K. Gould, and G. G. Brownlee. 1986. Cytotoxic $\mathrm{T}$ lymphocytes recognize influenza haemagglutinin that lacks a signal sequence. Nature (Lond.). 324:575-577.

19. McChesney, M., F. Tanneau, A. Regnault, P. Sansonetti, L. Montagnier, M. P. Kieny, and Y. Rivière. 1990. Detection of primary cytotoxic T lymphocytes specific for the envelope glycoprotein of HIV-1 by deletion of the env amino-terminal signal sequence. Eur. J. Immunol. 20:215-220.

20. Okamoto, H., M. Imai, M. Kametani, T. Nakamura, and M. Mayumi. 1987. Genomic heterogeneity of hepatitis B virus in a 54-year-old woman who contracted the infection through materno-fetal transmission. Jpn. J. Exp. Med. 57:231-236.

21. Kaneko, S., and R. Miller. 1989. Heterogeneity of the core gene sequence in a patient chronically infected with hepatitis B virus. J. Infect. Dis. 160:903904.

22. Bhat, R. A., P. P. Ulrich, and G. N. Vyas. 1990. Molecular characterization of a new variant of hepatitis B virus in a persistently infected homosexual man. Hepatology (Baltimore). 11:271-276.

23. Saiki, R. K., D. H. Gelfand, S. Stoffel, S. J. Scharf, R. H. Higuchi, G. T. Horn, K. B. Mullis, and H. A. Erlich. 1988. Primer-directed enzymatic amplification of DNA with a thermostable DNA polymerase. Science (Wash. DC). 239:487-491.

24. Tindall, K. R., and T. A. Kunkel. 1988. Fidelity of DNA synthesis by the Thermus aquaticus DNA polymerase. Biochemistry. 27:6013-6020.

25. Tong, S., J. Li, L. Vitvitski, and C. Trepo. 1990. Active hepatitis B virus replication in the presence of anti-HBe is associated with viral variants containing an inactive pre-C region. Virology. 176:596-603.

26. Tiollais, P., C. Pourcel, and A. Dejean. 1985. The hepatitis B virus. Nature (Lond.). 317:489-495.

27. Summers, J., and W. S. Mason. 1982. Replication of the genome of a hepatitis B-like virus by reverse transcription of an RNA intermediate. Cell. 29:403-415.

28. Liang, T. J., H. E. Blum, and J. R. Wands. 1990. Characterization and biological properties of a HBV variant. Hepatology (Baltimore). 12:204-212.

29. Blum, H. E., E. Galun, T. J. Liang, F. V. Weizsaecker, and J. R. Wands. 1991. A naturally occurring missense mutation in the polymerase gene terminating hepatitis B virus replication. $J$. Virol. 65:1836-1842.

30. Suzuki, T., N. Masui, K. Kajino, I. Saito, and T. Miyamura. 1989. Detection and mapping of spliced RNA from a human hepatoma cell line transfected with the hepatitis B virus genome. Proc. Natl. Acad. Sci. USA. 86:8422-8426.

31. Su, T.-S., C.-J. Lai, J.-L. Huang, L.-H. Lin, Y.-K. Yauk, C. Chang, S. J. Lo, and S.-H. Han. 1989. Hepatitis B virus transcript produced by RNA splicing. J. Virol. 63:4011-4018. 